\title{
To Study of The Physico-Chemical Parameters of GIRNA Project Near Panzangaon, Tal- Nandgaon, District- Nashik (M.S.) India
}

\author{
Shambharkar Rajesh. M
}

Assistant Professor, Department of Zoology, Arts, Commerce and Science College, Lasalgaon, Niphad, Nashik, Maharashtra, India

\begin{abstract}
This investigation reveal as the Physico-chemical parameters of Girna project were monitored over period of one year July 2007 to June 2008. The fresh water of the Girna project is mostly used for the drinking and Agricultural purposes. The study of different parameters like Temperature, Rain fall, pH, Turbidity, T.D.S., Dissolved Oxygen, Dissolved carbon dioxide, Total hardness, calcium, Magnesium, and Chloride were well studied and suggest that the quality of water is not polluted.
\end{abstract}

Keywords : Physico-Chemical Parameters, Girna Project, and Pollution

\section{INTRODUCTION}

The water is very important compound of the any ecosystem. Lakes, dams, ponds are important for fresh water habitats throughout many regions of the world, although the amount of water in them constitutes only a minute fraction of the total fresh water resource on Earth. A large proportion of the fresh water is stored as ice at higher altitudes and around the poles or as groundwater as the less than $0.5 \%$ is available for use by organisms, including for human civilization.

However, increasing of human population have resulted in accelerating demands of water supply for the drinking, industrial process, hygiene and agriculture. Fresh water has become a scarce commodity due to over exploitation and pollution of water. Increasing population and its necessities have lead to the deterioration surface and subsurface water.

Among various water resources on earth, oceans account for $97.6 \%$, ice caps and glaciers, $1.87 \%$; groundwater, $0.5 \%$; rivers, lakes and inland seas,
$0.02 \%$; soil moisture, $0.01 \%$; and atmosphere, $0.0001 \%$. There are three major global resources of water: a) precipitation over the earth's surface in the form of the rain, dew, and snow; b) surface water; as river and lakes; and c) underground water. The water bodies having still water are referred to as "lentic". Those water bodies having running water re called "lotic" These two ecosystem differ considerably in ecological, chemical and physical characteristics.

The water of good quality is required for living organisms. The quality of water resources is usually described according to its physical, chemical, and biological characteristic for the good quality of water resources large numbers of physicochemical and biological parameters are to be studied and must be found in normal range.

\section{METHODS AND MATERIAL}

The study of this water body specifically and collected the samples from different places of the Girna project. This project is located $74^{\circ}-39^{\prime}$ North Latitude and $20^{0} 29^{\prime} \mathrm{E}$ Longitude. The people of 
Nashik district and Jalgaon district were facing the problem of scarcity of water. The total catchment area of this project is 5552 hectors. Girna project built on the Girna River. The started of this project in the year 1955 and its completed in the year 1965.

The study period of one year from July-2007 to June 2008, the total period of rain fall data was collected from the project office at Chalisgaon. The Atmospheric temperature (AT) was measured and recorded with the help of mercury thermometer. The water temperature, $\mathrm{pH}$, Dissolved oxygen (DO), Dissolved carbon dioxide were recorded by using advanced water analysis portable kit.

All studied parameters were analyzed when the sample was collected on spots. As early as possible 6 am. to 8 am., early morning collect the sample from station A and station $\mathrm{B}$, the distance between station 1.5 to $2 \mathrm{~km}$. The total estimation analyzed in the laboratory immediately like calcium, magnesium and chloride.

\section{RESULTS AND DISCUSSION}

The Physico-chemical parameters such as Rain fall, Atmospheric temperature (AT), water temperature, pH, Turbidity, T.D.S., Dissolved oxygen (DO), Dissolved Carbon Dioxide, Calcium, Magnesium and Chloride were analyzed from station A, station B and station $C$ of the Girna project near Panzangaon, DistNashik. All Physico-chemical parameters were analyzed and discussed seasonally and its variations across are graphically shown in the fig.
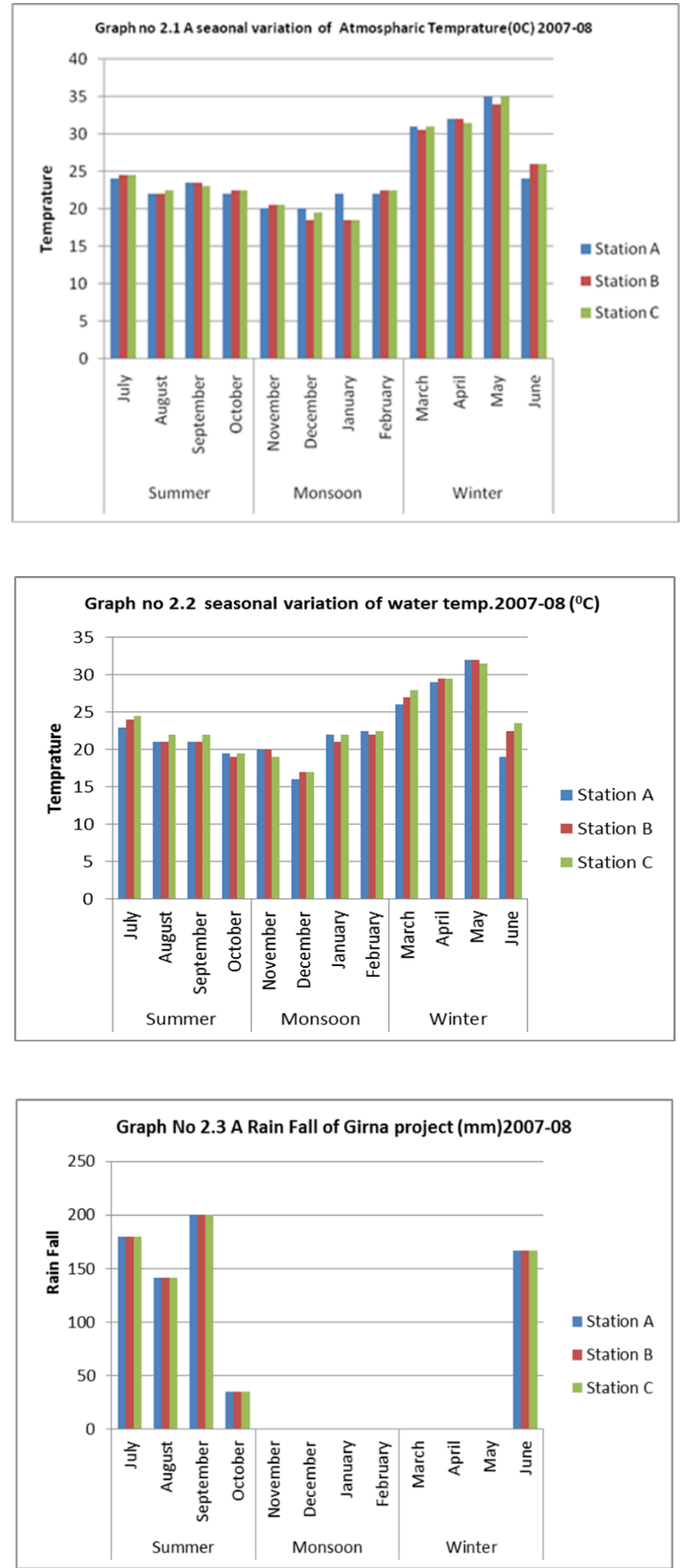

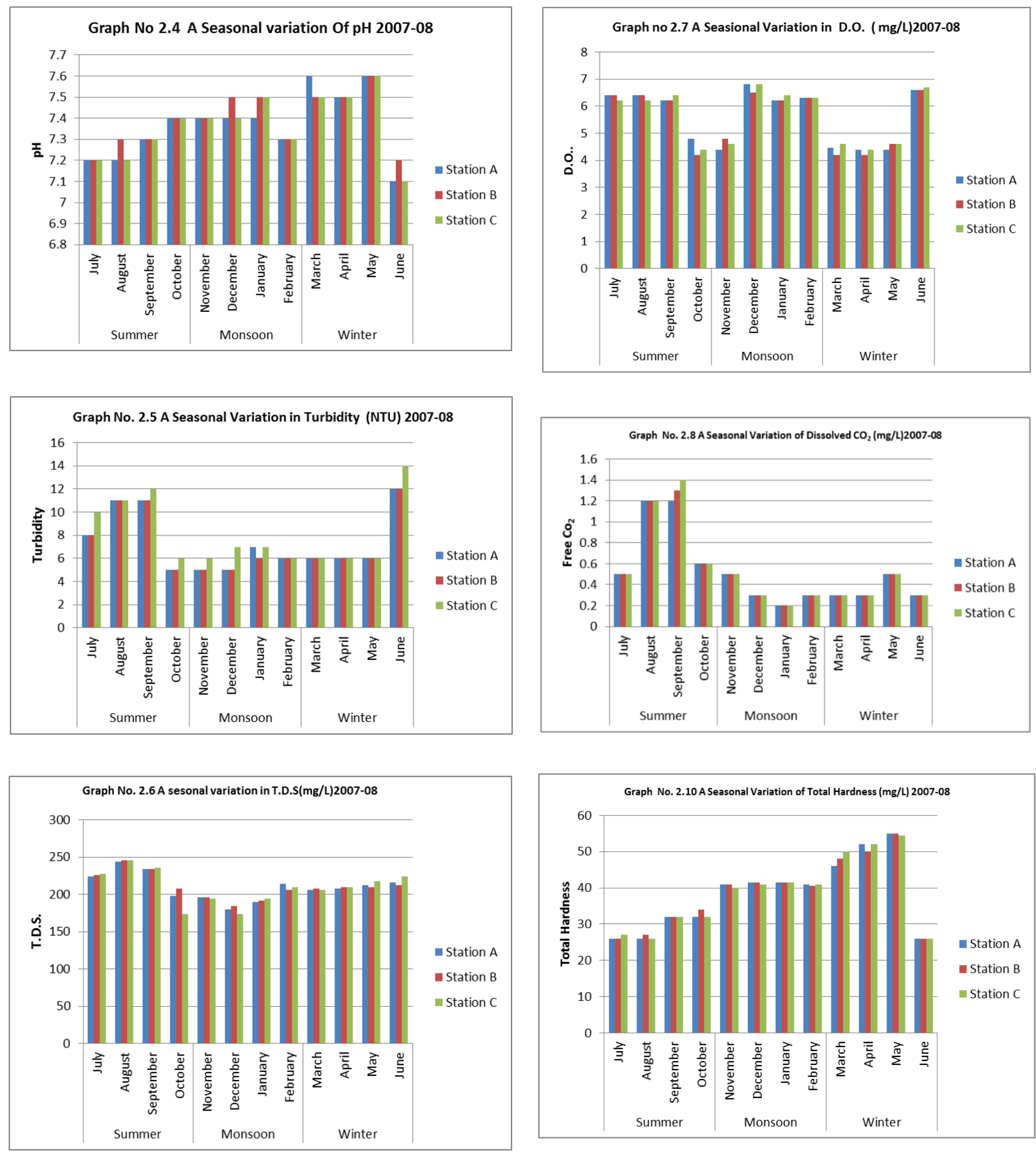


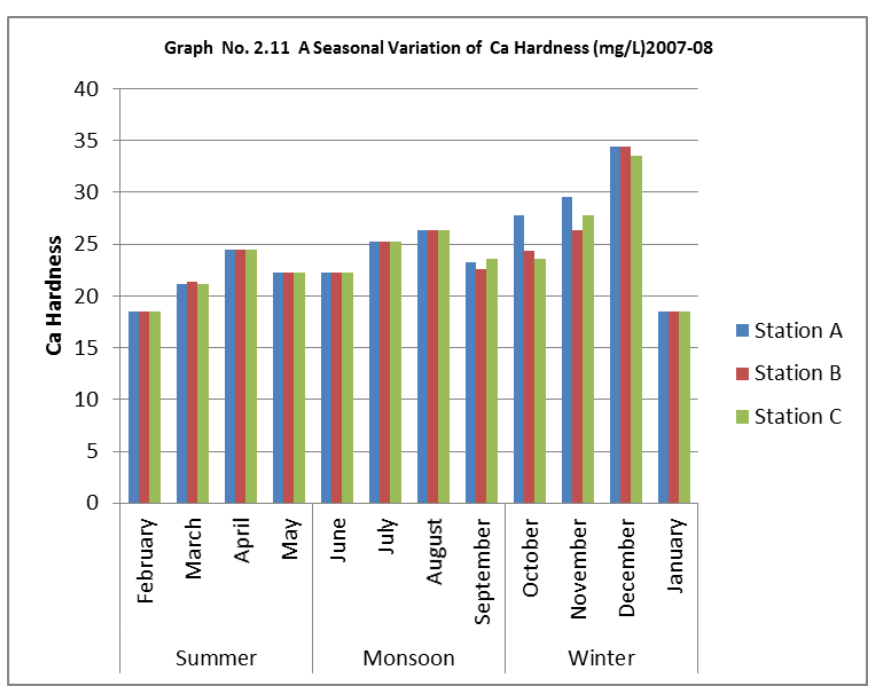

\section{Rain fall :}

In the present study of the rainfall July -2007 to June 2008 was recorded. The maximum rain fall was recorded in the Monsoon was $200 \mathrm{~mm}$.at all the stations in the month of September and minimum 32 $\mathrm{mm}$. in the month of July.

\section{Atmospheric temperature:}

The atmospheric temperature was similar at both the sampling stations, they have distance between stations A and station B, 1.5 to $2.00 \mathrm{~km}$. The atmospheric temperature during the July 2007 to 2008 recorded maximum in summer $35^{\circ} \mathrm{C}$ at the station A and station C. In the month of May 2008 and minimum was $22.5^{\circ} \mathrm{C}$, at station $\mathrm{B}$ and station C in the month of December and January 2008. The maximum atmospheric temperature recorded in monsoon $26{ }^{\circ} \mathrm{C}$ at $\mathrm{B}$ station in the month of June and minimum was $23.5^{\circ} \mathrm{C}$ at the station $\mathrm{B}$ in the month of September2007. In the winter the maximum temperature was recorded $22.5^{\circ} \mathrm{C}$ at station $\mathrm{C}$ in the month of October 2008 and minimum $18.5^{\circ} \mathrm{C}$ at station A and station B in the month of January.

\section{Water temperature:}

In present investigation the temperature of water was similar almost of all the sampling stations A station B and station C. During the period July 2007 to
June2008 the water temperature recorded in summer maximum $32^{\circ} \mathrm{C}$ at station $\mathrm{C}$ and minimum $22^{\circ} \mathrm{C}$ at the station B in the month of February 2008. The maximum water temperature in monsoon was $24.5^{\circ}$ $C$ at station C and station B in the month of July 2007 and minimum temperature was $21^{\circ} \mathrm{C}$ at the station $\mathrm{A}$ and station B in the month of August and September 2007. The maximum water temperature recorded in winter was $22^{\circ} \mathrm{C}$ at station $\mathrm{A}$ and station $\mathrm{C}$ and minimum was $16^{\circ} \mathrm{C}$ at station $\mathrm{A}$ in the month of December 2007.

\section{Hydrogen ion concentration ( $\mathrm{pH})$ :}

The present investigations of the $\mathrm{pH}$ at the station $\mathrm{A}$, Station B and station C, varied from 7.1 to 7.6. In the year July 2007 to June 2008 the $\mathrm{pH}$ recorded in summer maximum value was 7.6 at all stations in the month of May 2008. The minimum pH 7.3 at all stations in the month of February 2008.The maximum $\mathrm{pH}$ recorded in the monsoon in July 2007 to June was 7.3 at the station $\mathrm{C}$ and minimum 7.1 at the station A and station C in the month of July 2007. The maximum $\mathrm{pH}$ recorded in winter in July 2007 to 2008 was 7.5 at all stations in the month of November , December and January 2008 at the station B and station C and minimum 7.3 at all stations in the month of October and November 2007.

\section{Turbidity:}

The present investigation of the turbidity at station A and b. In the year July 2007 to June 2008 the turbidity recorded in summer maximum value was 6 NTU at all stations in the month of February to May 2008. The maximum turbidity recorded in the monsoon in the July 2007 to June 2008 was 14 NTU at station $C$ in the month of June 2008 and the minimum 7 NTU at the station A and B in the month of July 2007. The maximum turbidity recorded in winter in July 2007 to June 2008 the turbidity was 7 NTU at station C in the month of January 2008 and 
minimum 5 NTU at the station A and station B in the month of October and December.

\section{T.D.S:}

The present investigation of the T.D.S. at the station A station B and station C in the year July 2007 to June 2008.The maximum T.D.S was recorded 218 $\mathrm{mg} / \mathrm{L}$ at all stations in the month of May 2008 and minimum $214 \mathrm{mg} / \mathrm{L}$ at the station A in the month of February 2008.The maximum T.D.S was recorded in the monsoon in July 2007 to 2008 was $246 \mathrm{mg} / \mathrm{L}$ at the station B in the month of August 2007 and minimum $212 \mathrm{mg} / \mathrm{L}$ at the station $\mathrm{A}$ in the month of June 2008.The maximum T.D.S was recorded in winter in July 2007 to June 2008 was $208 \mathrm{mg} / \mathrm{L}$ at the station B in the month of October 2007 and minimum $174 \mathrm{mg} / \mathrm{L}$ at the station $\mathrm{C}$ in the month of December2007.

\section{Dissolved Oxygen:}

The present investigation the dissolved oxygen at station A, station B and station C was varied. In the year July 2007 to June 2008 the dissolved oxygen recorded in summer maximum value was $6.3 \mathrm{mg} / \mathrm{L}$ at the stations in the month of February 2008 and minimum was $4.2 \mathrm{mg} / \mathrm{L}$ at stations $\mathrm{A}$ in the month of March to April 2008. The maximum $6.3 \mathrm{mg} / \mathrm{L}$ was recorded in monsoon at the station $\mathrm{C}$ in the month of June 2008 and minimum $6.2 \mathrm{mg} / \mathrm{L}$ at the station $B$ in the month of August and September 2007.The maximum dissolved oxygen in winter during July 2007 to June 2008 was $6.8 \mathrm{mg} / \mathrm{L}$ at the station $\mathrm{A}$ and station C in the month of December 2007 and minimum $4.2 \mathrm{mg} / \mathrm{L}$ at the station $\mathrm{B}$ in the month of October 2007.

\section{Dissolved Carbon Dioxide:}

In the present study dissolved carbon dioxide at station A station B and station C was varied. During the period of July 2007 to June 2008 dissolved carbon dioxide in summer maximum $0.5 \mathrm{mg} / \mathrm{L}$ at all stations in the month of May 2008 and minimum value was $0.3 \mathrm{mg} / \mathrm{L}$ at all stations. The maximum dissolved carbon dioxide recorded in monsoon in July 2007 to June 2008 was $1.4 \mathrm{mg} / \mathrm{L}$ at all stations in the month of September 2007 and minimum $0.3 \mathrm{mg} / \mathrm{L}$ at all stations in the month of June 2008. The maximum dissolved carbon dioxide recorded in winter in July 2007 to June 2008 was $0.6 \mathrm{mg} /$ at all stations in the month of October 2007 and minimum $0.2 \mathrm{mg} / \mathrm{L}$ at all stations in the month of January and February 2008.

\section{Calcium:}

In present investigation the calcium hardness was varied at station $A$, station $B$ and station $C$. In the year July 2007 to June 2008 the calcium hardness in summer maximum value was $34.6 \mathrm{mg} / \mathrm{L}$ at the station A and station B in the month of May 2008 and minimum value was $22.6 \mathrm{mg} / \mathrm{L}$ at the station $B$ in the month of February 2008. The maximum calcium hardness recorded in the monsoon in the year July 2007 to June 2008 was $24.5 \mathrm{mg} / \mathrm{L}$ at all stations in the month of September 2007 and minimum $18.5 \mathrm{mg} / \mathrm{L}$ at all stations in the month of June, July 2008. The maximum calcium hardness recorded in winter July 2007 to June 2008 was $26.4 \mathrm{mg} / \mathrm{L}$ at all stations in the month of January 2008 and minimum $22.3 \mathrm{mg} / \mathrm{L}$ at all stations in the month of October and November 2007.

\section{Magnesium:}

In the present study the magnesium hardness at station A station B and station $C$ was varied. . In the year July 2007 to June 2008 the Magnesium hardness in summer maximum value was $25.60 \mathrm{mg} / \mathrm{L}$ at the station A and station C in the month of May 2008 and minimum value was $18.8 \mathrm{mg} / \mathrm{L}$ at the station $\mathrm{A}$ in the month of February 2008 The maximum magnesium hardness recorded in the monsoon in the year July 2007 to June 2008 was $12.9 \mathrm{mg} / \mathrm{L}$ at station 
A, B and C in the month of June and September and minimum $8.5 \mathrm{mg} / \mathrm{L}$ at all stations in the month of August 2007.The maximum magnesium hardness recorded in winter in July 2007 to 2008 was $16.8 \mathrm{mg} / 1$ at the station $\mathrm{A}$ and $\mathrm{C}$ in the month of December 2007 and minimum $12.5 \mathrm{mg} / \mathrm{L}$ at the station $\mathrm{C}$ in the month of October 2007.

\section{Chloride:}

The present investigation the chloride at station $\mathrm{A}$ and station $\mathrm{B}$ and station $\mathrm{C}$ was varied. In the year July 2007 to June 2008 the chloride recorded in summer maximum value was $26.3 \mathrm{mg} / \mathrm{L}$ at all stations in the month of May 2008 and minimum value was $13.10 \mathrm{mg} / \mathrm{L}$ at all stations in the month of February and march 2008. The maximum chloride recorded in the monsoon in the year July 2007 to June 2008 was $22.5 \mathrm{mg} / \mathrm{L}$ at all stations in the month of June and minimum $13.30 \mathrm{mg} / \mathrm{L}$ at all stations in the month of July to September 2007. The maximum chloride recorded in the winter in the year July 2007 to June 2008 was $21.28 \mathrm{mg} / \mathrm{L}$ at all stations in the month of November, December and January and minimum $11.40 \mathrm{mg} / \mathrm{L}$ at all stations in the month of October 2007.

\section{IV.CONCLUSION}

The study of water sample of different station A, B and $C$ of Girna Project reveals that the value of Physico-Chemical parameters were below the permissible limit given by the World Health Organization . Hence the water of Girna Project is fit for the consumption by the human beings.

\section{ACKNOWLEDGEMENT}

I express my deep sense of gratitude of my affectionate revered research Guide Dr. S.M. Kamble, Prof.Dr. K.B. Shejule, Dr. R.B. Patil, Dr. Dinesh Naik and Mr. Govindraoji Holkar (General Secretary of N.V.P. Mandal'S)

\section{REFERENCES}

[1]. Adoni, A.D. (1985): Work book on limnology. Indian MAB committee Dept. of Environment, Govt. of India.

[2]. Agarwal, A. S. (1982): State of India's freshwater, A citizen report center for science and environment New Delhi.

[3]. APHA (1985) : Standard Methods for Examination of Water and Waste Water16 Ed. American Public Health Association, Washington (D.C.)

[4]. APHA (1989) : Standard methods for the examination of Water and Wa1ste Water,17th Edition APHA, Washington D.C.

[5]. APHA (1992) : Standard methods for the examination of Water and Waste Water.18th edition, APHA, Washington D.C.

[6]. APHA (1996). Standard methods for the examination of Water and Waste, 18th Ed., APHA, AWWA, WPCF, New York.

[7]. APHA (1998) : standard methods for the examination of water and waste water. 20 th Edition, American Public Health Association, Washington D.C.

[8]. Bandella, N.N., D. P.Vaidya and V. S.Lomte (1998): Seasonal temperature changes and their influence on the level of carbon-dioxide and $\mathrm{pH}$ of Borul dam Water J.Aquatic Biol.13(1):4346.

[9]. Bankar, A.B. , K. Poojtha, S. Thirumala, S. Manjappa and E.T.Puttaiah (2010): Physicochemical analysis of kathralu pond water near chitradurga, Karnatka, J. Aqua. Bio. 25 (2); 7074.

[10]. Baruah, B.K. talukdar S. and C.R. Borthakur (1998): Water Quality of Ponds in Chandrapur 
area of Kamrup district, Assam Eviron \& Eco. 16(2):254-256.

[11]. Bhagde Rupendra, V. (2005) : Study of physicochemical parameters of the Bhatye estuary on Ratnagiri cost of Maharashtra. J.Aqua. Biol. Vol. 20 (2) : 113-116.

[12]. Bhaskar, D. S. saxena, R.P. and Pandey, G. N. (1979): Physiological imbalances due to hexavelent Chromium on fresh water algae. Indian J. Envi, 2(3):234-243.

[13]. Bhatt, S.D. and J.K.Pathak (1992) : Assessment of water quality and aspects of pollution in a stretch of river Gomti (Kumaun: Lesser Himalaya). J.Environ. Biol. 13(2) : 113-126.

[14]. Delphine Rose, M.R., A. Jeyaseeli, A. Joice Mary and J. A. Rani (2008): Characteristics of ground water quality of selected areas of Dndugal district, Tamil Nadu. J. Aqua. Bio. 123(1): 40-43.

[15]. Deshmukh, J.U. and Ambore, N.E. (2006) : Seasonal Variations in physical aspects of Pollution in Godavari River at Nanded,Maharashtra, India .J. aqua.Biol. Vol. 22(20):93-96.

[16]. Deshpande S. M. and Gondwale V. (2009): Physico-chemical analysis of ground water in the Chikalthana industrial complex, Aurangabad, Maharashtra, J. Aqua.Bio. Vol. 24 (2);99-102.

[17]. Fasihuddin Md. Jyotsna Kumari (1990): Seasonal variations in Physico-chemical properties and Plankton periodicity in a freshwater pond at Bhagalpur, India Environ. Ecol. 8(3): 929-932.

[18]. Fotedar Amita and B.K. Fotedar (2008): Water chemistry of Tawi river from Nagrota to Kanpur area, Jammu, Himalaya, (J \& K); J. Aqua.Bio. Vol. 23 (2);77-86

[19]. Fotedar Amita, B.A. Loan and B.K. Fotedar (2010): Water chemistry of Loran mandi
Nallah, Poonch area, (J \& K) state. J. Aqua.Bio. 25 (2);75-84

[20]. Ganpati, S.V.(1962) : Studies on the sources of the Madras City water supply and on other waters of Madras staete.D.Sc.Thesis,University of Madras, Madras (India).

[21]. Goel, P.K. Gopal B. and Trivedy R.K. (1986): Limnological studies of a few freshwater bodies In southwestern Mahrashtra with special reference to their chemistry and phytoplanktons Poll. Res. 5(2) 79-84.

[22]. Gupta, S. and M. Gupta (1997) : Domestic water supply and environmental effects. Water and Basic Environmental Technology, 1st Edition Anmol Publication Pvt. Ltd. New Delhi : 225275.

[23]. Gupta, S. (1989) : $\mathrm{pH}$ and alkalinity concentration in drinking water of Jodhpur, its impact asseeement on a fresh water fish, Cyprinus carpio. Ph.D. thesis, university of Jodhpur, India. Pp 181.

[24]. Ingole, S.B., R.G. Pawale and P.N. Wavde(2009) : Water quality studies at Majalgaon Dam, Beed District Maharashtra. J.Aqua. Biol., Vol. 24(1),1-6.

[25]. Jawale , A.K. and Patil S.A. (2009). Physicochemical characteristics and phytoplankton abundance of Mangrul Dam, Dist. - Jalgaon, Maharashtra, India. J.Aqua.Bil. Vol. 24(1) 1-6.

[26]. Kadam, M. S., Pampatwar, D.V. and Mali, R. P.(2007) : Seasonal Variations in different physico-chemical Characteristics in Masoli reservoir of Parbhani district, Maharashtra. J. Aqua. Biol. Vol. 22(1): 110-112.

[27]. Karadkhele , S.V. Lokhande, M.V., Rathod, D.S., Shembekar, V.S.and Patil. S.M.(2008) : Studies on physic-chemical characteristics of recreation water body in Nana Nani Park, Latur, Maharashtra. J.Aqua. Biol. 23(1) 55-58. 
[28]. Kodarkar (Ed.) (2006) : Methodology for water analysis - Physico-chemical, Biological and Microbiological. IAAB Publication No.2.3rd Edition. IAAB, Hyderabad. : 1-107.

[29]. Kodarkar, M.S. (1992) : Methodology for water analysis, Physico-chemical Biological and Microbiological. Indian Association of Aquatic Biologist, Hyderabad. Pub. -2.P. 50.

[30]. Kodarkar, M. S., Diwan, A. D.,Murugan, N., Kulkarni, K.M., Anuradha, R. (1998) : Methodology for water analysis, Indian Association of Aquatic Biologists, IAAB, publication No.2.

[31]. Koorosh, Jalilzadeh, Sadanand M., Yamakanamardi and K. Alttaf (2009); Physicochemical parameters of three contrasting lakes of Mysore, Karnatka.

[32]. Michael, R. G. (1973) : Seasonal trends in physico - chemical factors and plankton of a fresh water fish and their role in fish culture. Hydrobiologia, 30, $144-160$.

[33]. Patil, Anil R. and Lohar Prakash (2009): Seasonal variation in Physico-chemical Parameters of River Patalganga, Raigad district,Maharashtra. J. Aqua.Biol. 24 (2):109112.

[34]. Pawar S.K. and J.S. Pulle (2005): Studies on Physico-chemical parameters in Pethwadaj Dam. Nanded Dist.of Maharashtra J. Aqua. Biol. Vol.20 (2) : 123-128.

\section{Cite this article as :}

Shambharkar Rajesh. M, "To Study of The PhysicoChemical Parameters of GIRNA Project Near Panzangaon, Tal- Nandgaon, District- Nashik (M.S.) India", International Journal of Scientific Research in Science and Technology (IJSRST), Online ISSN : 2395-602X, Print ISSN : 2395-6011, Volume 6 Issue 2, pp. 472-479, March-April 2019. Available at doi : https://doi.org/10.32628/IJSRST196268 Journal URL : http://ijsrst.com/IJSRST196268 